\title{
Holoprosencephaly and sacral agenesis in a fetus with a terminal deletion $7 \mathrm{q} 36 \rightarrow 7 \mathrm{qter}$
}

\author{
Nicole Morichon-Delvallez, Anne-Lise Delezoide, Michel Vekemans
}

\begin{abstract}
We describe here a fetus with holoprosencephaly and signs of caudal deficiency sequence. Chromosome examination showed a de novo balanced reciprocal translocation (7;22) (q36;q11) with loss of the derivative chromosome 22 in $50 \%$ of the cells examined. The present report and available published data indicate that the terminal region of the long arm of chromosome 7 contains genes implicated in the development of the central nervous system and the caudal region.

( $\mathcal{F}$ Med Genet 1993;30:521-4)
\end{abstract}

Among chromosomal abnormalities associated with holoprosencephaly, aberrations of chromosomes 13 and 18 are the most common. There is, however, a long list of other numerical and structural chromosomal abnormalities in which holoprosencephaly may be found. For example, several reports associating holoprosencephaly with a terminal $7 \mathrm{q}$ deletion suggest that a putative locus for holoprosencephaly resides at or near $7 \mathrm{q} 36 .{ }^{1}$ We describe

Service d'Histologie, Embryologie et de Cytogénétique, Hôpital

Necker-Enfants

Malades, 149 rue de Sèvres, 75015 Paris, France.

N Morichon-Delvallez A-L Delezoide $M$ Vekemans

Correspondence to Dr Morichon-Delvallez.

Received 17 July 1992.

Revised version accepted 20 October 1992.

Figure 1 Face of the proband at 24 weeks of gestation, showing cebocephaly (hypotelorism, monorhinia, microstomia). here another patient with a translocation involving chromosome 7 and chromosome 22 whose malformations included holoprosencephaly and sacral agenesis.

\section{Case report}

Abnormalities of the fetus were first detected on ultrasound at 23 weeks' gestation. The skull was filled with fluid, leaving only a thin layer of brain tissue, and the corpus callosum was absent. There were no midline structures. After counselling the parents decided to terminate the pregnancy. Examination of the stillborn male fetus showed microcephaly with cebocephaly and hypotelorism, right exophthalmia, low set and abnormally shaped ears, and micrognathia (fig 1). In addition the fetus had caudal agenesis. At necropsy, the following features were found: semilobar holoprosencephaly with a single dilated ventricle (fig 2), arhinencephaly, hypoplasia of the optic nerve, bilateral microphthalmia, and a right cataract. No congenital heart defect or hypoplasia of the thymus were noted. Radiological examination showed brachymesophalangism of the fifth finger, hypoplasia of the fifth lumbar vertebra, and absence of the sacral vertebrae (fig 3 ). The family history was unremarkable, there was no consanguinity, and the 30 year old mother was not diabetic. A previously born 4 year old boy was healthy.

CYTOGENETIC STUDIES

Fibroblast cultures from a lung specimen from the fetus were studied with standard RTB banding; $50 \%$ of the cells examined carried a balanced reciprocal translocation $46, \mathrm{XY}$,

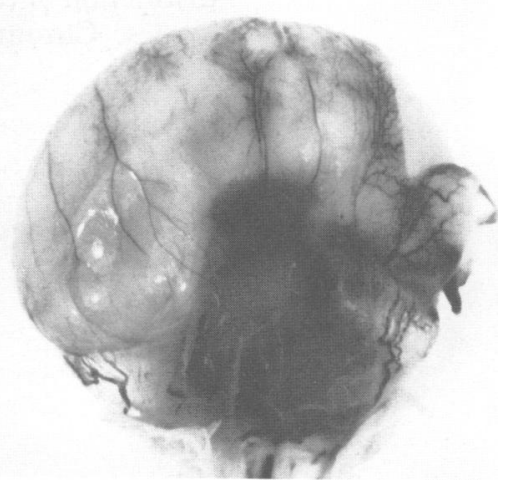




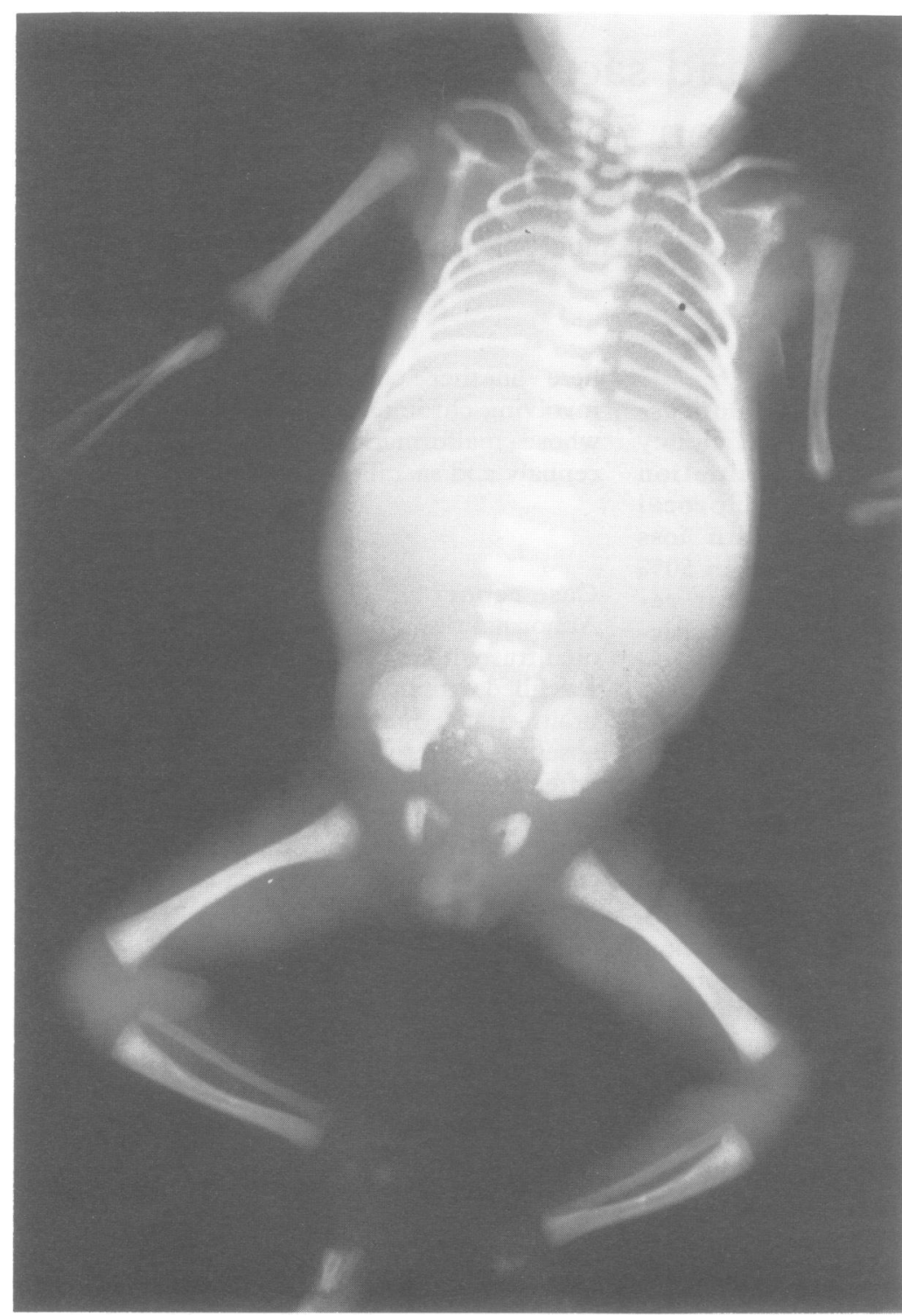

Figure 3 Radiographic appearance of the lower part of the spine: abnormally low number of sacral vertebral bodies which are less developed and irregular.

$t(7 ; 22)(q 36 ; q 11)$. The other half had apparently lost the derivative chromosome 22 and were therefore monosomic for the distal part of the long arm of chromosome 7 (7q36 $\rightarrow$ qter) and for the short arm, the centromeric region, and the proximal part of the long arm of chromosome 22 (22pter $\rightarrow$ q11) (fig 4). Study of the short arm heteromorphisms did not allow distinction of the maternal and paternal homologues. Chromosome analysis of the parents

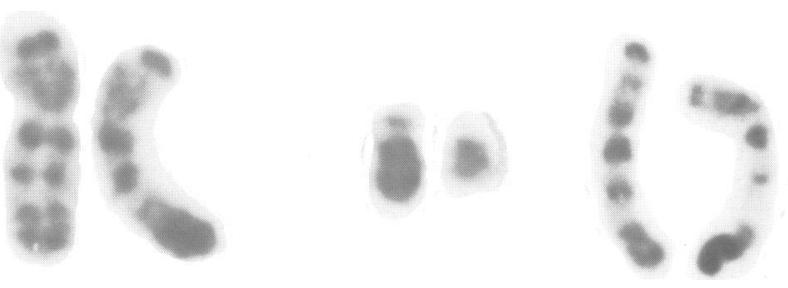

Figure $4 R$ banded partial karyotype of the fetus showing the balanced reciprocal translocation $(7 ; 22)$ and the loss of $\operatorname{der}(22)$ in $50 \%$ of cells examined. was normal. A fibroblastic cell line of the patient is available in our laboratory.

\section{Discussion}

Since the first case of a long arm deletion of chromosome 7 reported by de Grouchy et al, ${ }^{2}$ numerous authors have described similar deletions. This has allowed the delineation of a syndrome including numerous non-specific facial signs such as microcephaly, prominent forehead, cleft lip and palate, bulbous nasal tip with broad nasal bridge, hypertelorism, auricular malformation, micrognathia, abnormal genitalia in males, developmental delay, and pre- or postnatal growth retardation. ${ }^{3-5}$ Holoprosencephaly has rarely been reported. ${ }^{6}$

The association of terminal $7 \mathrm{q}$ deletion with developmental anomalies of the prosencephalon has been well documented (table). Hatziioannou et al, ${ }^{1}$ re-examining the family described by Krauss $e t a l^{17}$ where a reciprocal translocation $(7 ; 9)$ was segregating, found minor signs of holoprosencephaly in three members. Two were carriers of the unbalanced chromosomal complement resulting in a deletion of the $7 q 36 \rightarrow$ qter region, but one carried an apparently balanced translocation. From these data, Hatziioannou et al ${ }^{1}$ concluded that a putative locus for holoprosencephaly resides at or near 7qter.

Interestingly, the $7 q$ deletions associated with holoprosencephaly mostly resulted from a malsegregation of an inherited translocation, , $^{181012-15}$ whereas deletions occurring de novo are often associated with minor forms or absence of holoprosencephaly. These findings emphasise the importance of the telomeric region of the long arm of chromosome 7 $(7 q 36 \rightarrow 7 q t e r)$ in preventing the occurrence of holoprosencephaly. ${ }^{1}$

The present fetus with an apparently balanced de novo reciprocal translocation between chromosomes 7 and 22 had two major anomalies: semilobar holoprosencephaly and partial sacral agenesis. Fifty percent of the cells had, however, an unbalanced chromosomal complement resulting from a loss of the derivative chromosome 22 (22pter $\rightarrow 22 \mathrm{q} 11)$. Whether this event occurred early during embryogenesis is difficult to establish as no other fetal tissue could be examined.

Cytogenetic analysis of patients with $\mathrm{Di}$ George syndrome has shown that unbalanced translocations leading to monosomy 22pter $\rightarrow$ $22 \mathrm{q} 11$ are particularly common..$^{18}$ In addition, Scambler et al $^{19}$ showed that Di George syndrome can be associated with submicroscopic deletions of the $22 \mathrm{q} 11$ region. Also, Back et al $^{20}$ described holoprosencephaly and arhinencephaly in a fetus with an unbalanced reciprocal translocation $(11 ; 22)$ with partial monosomy of chromosome 22 (pter $\rightarrow \mathrm{q} 11$ ). The proximal position of the breakpoint observed in the translocation carried by our fetus presumably explains the absence of signs associated with Di George syndrome.

We conclude therefore that one of the breakpoints of the translocation (at 7q36) is responsible for the holoprosencephaly observed in 


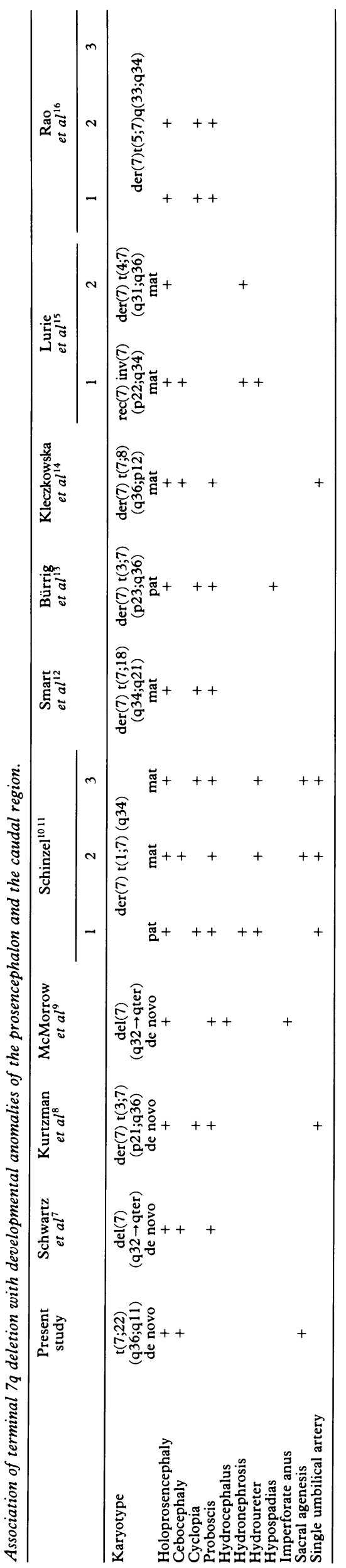


our patient. Two hypotheses might be considered: either a loss of function of the gene at the breakpoint level or monosomy for the genes located on the terminal segment $7 q 36 \rightarrow 7 q$ ter.

In addition, there is also some evidence to suggest that genes in this region might be implicated in the development of the caudal region. For example, in 1988, SchranderStrumpel et $a l^{1}$ described a boy with a terminal deletion $7 q(7 q 32 \rightarrow 7 q t e r)$ and partial sacral agenesis. They found four other cases with a terminal deletion of chromosome $7 q$ and various signs of caudal deficiency sequence ${ }^{3112223}$ and postulated that the caudal deficiency sequence was part of this chromosomal syndrome. Similarly, in 15 cases where a terminal deletion of the long arm of chromosome 7 was associated with holoprosencephaly, signs of caudal deficiency sequence were found in nine.

In conclusion, we suggest that the terminal region of the long arm of chromosome 7 contains genes implicated in the development of the central nervous system and the caudal region.

The authors thank Stéphane Loison and Marie-Pierre Pinson for their expert technical support and Michèle Le Drévès for typing the manuscript.

1 Hatziioannou AG, Krauss CM, Lewis MB, Halazonetis TD. Familial holoprosencephaly associated with a translocation breakpoint at chromosomal position $7 \mathrm{q} 36 . \mathrm{Am} f$ Med Genet 1991;40:201-5.

2 de Grouchy J, Veslot J, Bonnette J, Radot M. A case of ?6pchromosomal aberration. Am ₹ Dis Child 1968;115:93-9.

3 Harris EL, Wappner RS, Palmer CG, Hall B, Seashore MR, Breg WR. 7q deletion syndrome (7q32 $\rightarrow 7 \mathrm{qter})$ Clin Genet 1977;12:233-8.

4 Gibson J, Ellis PM, Forsyth JS. Interstitial deletion of chromosome 7: a case report and review of the literature. Clin Genet 1982;22:256-65.

5 Young RS, Weaver DD, Kukolich MK, Heerema NA, Palmer CG, Kawira EL. Terminal and interstitial deletions of the long arm of chromosome 7: a review with five tions of the long arm of chromosome 7: a review
6 Friedrich W, Osterballe O, Stenbjerg S, Jorgensen J. A girl with karyotype 46,XX, del (7) (pter $\rightarrow$ q32). Hum Genet 1979; 51:231-5.

7 Schwartz S, Meekins J, Panny SR, Chen-Chih JS, Cohen MM. Cebocephaly-holoprosencephaly in a newborn girl with a terminal 7q deletion 46XX, del (7) (pter $\rightarrow$ q32). Am with a terminal 7q deletion $46 x$

8 Kurtzman DN, Van Dyke DL, Rich CA, Weiss L. Duplication 3 p21 $\rightarrow$ 3pter and cyclopia. Am $f$ Med Genet 1987;27:33-7.

9 McMorrow LE, Toth IR, Gluckson MM, Leff A, Wolman SR. A lethal presentation of de novo deletion 7q. $\mathcal{F}$ Med Genet 1987;24:629-31.

10 Schinzel A. Cyclopia and cebocephaly in two newborn infants with unbalanced segregation of a familial translocation $t$ rcp. $(1 ; 7) \quad(\mathrm{q} 32 ; \mathrm{q} 34)$. Am $\mathcal{f}$ Med Genet 1984;18:153-61.

11 Schinzel A. A further case of cyclopia due to unbalanced segregation of a previously reported $\operatorname{rcp}(1 ; 7)(32 ; \mathrm{q} 34)$ familial translocation. Am $\mathcal{F}$ Med Genet 1986;24:205-6.

12 Smart RD, Ross J, Amann G, Nelson MM. Cyclopia as a result of an unbalanced familial translocation, rcp $(7 ; 18)$ (q34;q21). Am $¥$ Med Genet 1986;24:269-72.

13 Bürrig KF, Gebauer J, Terinde R, Pfitzer P. Case of cyclopia with an unbalanced karyotype attributable to a cyclopia with an unbalanced karyotype attributable

14 Kleczkowska A, Fryns JP, Moerman PH, Vandenberghe K, Van den Berghe $\mathrm{H}$. Holoprosencephaly in a fetus with a $46 \mathrm{XX}$, der $(7), \mathrm{t}(7 ; 8)(\mathrm{q} 36.1 ; \mathrm{p} 12)$ mat karyotype. Ann 46XX, der (7), t $t(7 ; 8)$ (q36.1;

15 Lurie IW, Ilyina HG, Podleschuk LV, Gorelik LB, Zaletajev DV. Chromosome 7 abnormalities in parents of children with holoprosencephaly and hydronephrosis. $A m \mathcal{F}$ Med Genet 1990;35:286-8.

16 Rao N, Muenke M, Berry M, Pettenati MJ. Holoprosencephaly due to familial translocation $t(5 ; 7)(\mathrm{q} 33 ; \mathrm{q} 34)$ : non random association of $7 \mathrm{q} 34 \rightarrow \mathrm{qter}$. Am $\mathcal{F}$ Med Genet 1991;49:suppl 1509.

17 Krauss CM, Liptak KJ, Aggarwal A, Robinson S. Inheritance and phenotypic expression of a $\mathrm{t}(7 ; 9)(\mathrm{q} 36 ; \mathrm{q} 34) \mathrm{mat}$. Am ₹ Med Genet 1989;34:514-19.

18 Greenberg F, Elder FFB, Haffner P, Northrup H, Ledbetter DH. Cytogenetic findings in a prospective series of patients with Di George anomaly. Am $f$ Hum Genet patients with 1 .

19 Scambler PJ, Carey AH, Wyse RKH, et al. Microdeletions within $22 \mathrm{q} 11$ associated with sporadic and familial $\mathrm{Di}$ within 22q11 associated with sporadic and

20 Back E, Stier R, Böhm N, Adlung A, Hamester H. Partial monosomy 22 pter $\rightarrow$ q11 in a newborn with the clinical monosomy $22 \mathrm{pter} \rightarrow \mathrm{q} 11$ in a newborn with the clinical
features of trisomy 13 syndrome. Ann Genet (Paris) features of tris

21 Schrander-Strumpel C, Schrander J, Fryns JP, Hamers G Caudal deficiency sequence in 7q terminal deletion. $A m \mathcal{F}$ Med Genet 1988;30:757-61

22 Baumann W, Zabel B, Otte J, Weitzel D. Klinisches Bild bec terminaler Deletion am langen Arm des chromosoms Wr7. In: Klinische Genetik in der Pädiatrie. 2nd symposium. Stuggart: Thieme 1980: 209-13.

23 Nistrup Madsen H, Lundsteen C, Steinrud S. A case of partial deletion of the long arm of chromosome 7 (7q34 $\rightarrow$ 7qter) Dan Med Bull 1983;30:14-16. 